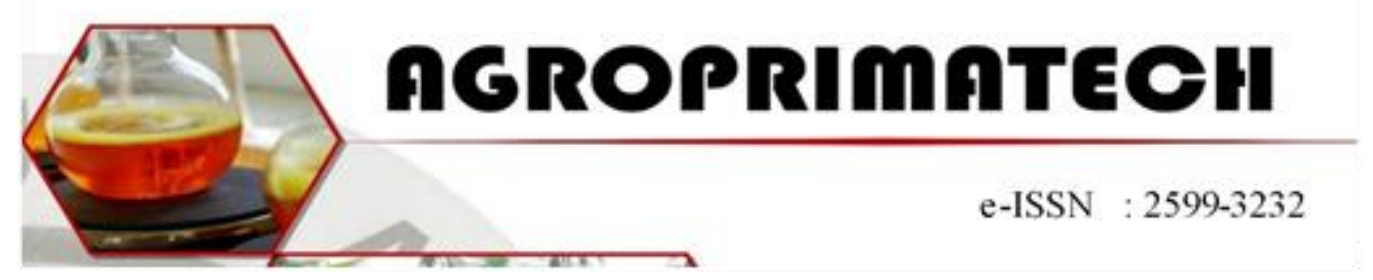

\title{
RESPON PEMBERIAN PGPR (PLANT GROWTH PROMOTING RHIZOBACTERIA) DENGAN DOSIS DAN LAMA PERENDAMAN TERHADAP PERTUMBUHAN Mucuna bracteata
}

\author{
IRFAN ARDIANSYAH ${ }^{1}$, NUR ARIYANI AGUSTINA ${ }^{2}$ \\ 1,2 Fakultas Agro Teknologi, Universitas Prima Indonesia, Medan \\ Email:nurariyaniagustina@unprimdn.ac.id
}

\begin{abstract}
ABSTRAK
Penelitian ini memiliki tujuan untuk memahami dampak pertumbuhan Mucuna bracteata setelah pemberian PGPR (Plant Growth Promoting Rhizobacteria) dengan dosis dan waktu perendaman yang berbeda. Penelitian ini memanfaatkan metode eksperimental dengan rancangan acak kelompok pola faktorial. Faktor pertama adalah dosis PGPR dengan 4 taraf: $0 \mathrm{ml}(\mathrm{K} 0), 5 \mathrm{ml}(\mathrm{K} 1), 10 \mathrm{ml}(\mathrm{K} 2), 15 \mathrm{ml}(\mathrm{K} 2)$ dan faktor kedua adalah waktu perendaman dengan 4 taraf: 0 menit (P0), 30 menit (P1), 60 menit (P2), 90 menit (P3). Data dianalisis memanfaatkan sidik ragam (Analysis of Variance) dengan signifikan $5 \%$. Berdasarkan hasil analisa data yang diperoleh bahwa pemberian larutan PGPR memiliki dampak nyata atas jumlah daun, berat kering akar serta berat segar akar. Pemberian larutan PGPR dengan lama perendaman tidak menghasilkan dampak nyata atas berat kering akar, berat segar akar, berat kering tajuk, berat segar tajuk, jumlah daun, panjang sulur, jumlah daun, serta panjang akar. Interaksi antara pemberian larutan PGPR dan waktu perendaman tidak memiliki dampak nyata atas pertumbuhan Mucuna bracteata (berat kering akar, berat segar akar, berat kering tajing, berat segar tajuk, jumlah daun, panjang sulur, jumlah daun, serta panjang akar).
\end{abstract}

Kata Kunci: Mucuna, Rhizobacteria, Dosis, Lama Perendaman

\section{PENDAHULUAN}

Mucuna bracteata adalah species kacang yang dapat bertumbuh dalam waktu singkat, mempunyai kapabilitas fiksasi $\mathrm{N}$ yang baik, mempunyai toleransi yang baik atas naungan, serta memiliki kandungan sangat senyawa fenolik cenderung tinggi sehingga tidak diminati oleh hewanhewan ternak ruminansia maupun hama (Harahap et al., 2008). Mucuna bracteta umumnya dimanfaatkan di perkebunan Indonesia karena dibandingan dengan penutup tanah yang lain, tanaman ini mempunyai kandungan biomassa yang lebih banyak. Perkebunan karet serta umumnya menggunakan tumbuhan ini pada areal reboisasi (Siagian, 2003). Aktifitas penanaman LCC (legume cover crop) sebagai penutup tanah ini tujuannya mempersiapkan kondisi yang sesuai bagi petani perkebunan khususnya tanaman kelapa sawit dengan harapan mencapai produksi yang tinggi dan menutupi permukaan tanah sehingga menghambat pertumbuhan gulma dan mengurangi 
kompetisi hara dalam kelapa sawit (Pahan, 2011).

Namun, masalah yang sering di

hadapi oleh petani dalam mengembangkan

tanaman Mucuna breacteata yakni

kesulitan akses bibit unggul sehingga mengakibatkan daya tumbuh yang kurang baik. Hal tersebut diakibatkan oleh berbagai macam faktor diantaranya adalah keberadaan unsur hara. Unsur hara adalah faktor yang paling utama untuk media penanaman, akses bagi unsur hara akan berpengaruh terhadap perkembangan tumbuhan yang ditanam di atasnya. Pemupukan biasanya dilaksanakan guna memenuhi kebutuhan tanaman akan unsur hara (Khasanah, 2012).

Dalam meningkatkan pertumbuhan dari tanaman faktor lainnya adalah pengaplikasian Plant Growth Promoting Rhizobacteria (PGPR). PGPR adalah pemicu atau mendorong perkembangan dari berbagai mekanisme yang mengkoloni perakaran melalui bakteri (Ibien et al., 2012). PGPR merangsang pertumbuhan tanaman sehingga meningkatkan pertumbuhan tanaman karena mempunyai bakteri yang mengkoloni akar dengan mensintesis zat regulator pertumbuhan seperti sitokinin, etilen, asam indol asetatm dan giberelin sebagai penyediaan zat hara yang menangkap $\mathrm{N}_{2}$ di udara secara ambiosis kemudian melarutkan hara $\mathrm{P}$ di tanah, serta sebagai pengontrol patogen tanah (biopractants) dengan cara memproduksi metabolit anti patogen (Husen, et al., 2006).

Menurut Santoso et al., (2014) perendaman benih dapat menghasilkan bibit yang unggul dan mempercepat pertumbuhan kecambah. Proses ini juga dilakukan dengan ambisisi yang mengaktifkan enzim enzim didalamnya pada laju reaksi.Perendaman benih perlu diperhatikan kosentrasi dan waktu perendaman supaya tidak terhambatnya perkecambahan (Sutopo, 2010).

\section{METODE PENELITIAN}

\section{Tempat dan Waktu}

Penelitian akan dilaksanakkan di lahan pertanian penduduk di Desa Sidodadi Ramunia, Kecamatan Beringin, Sumatera Utara pada bulan April sampai dengan Juni 2020 Pengovenan dilakukan di PPKS Medan.

\section{Alat dan Bahan}

Alat yang dimanfaatkan pada studi ini yakni: ayakan, pisau tajam, gunting, cangkul, gembor, gelas ukur, ember, meteran, tali rafia, paranet, bambu, buku, oven, timbangan analitik, kamera, penggaris serta alat tulis.

Bahan yang dimanfaatkan pada studi ini yakni biji Mucuna bracteata, PGPR, polybag $(22 \times 15 \mathrm{~cm})$ dan tanah top soil.

\section{Rancangan Penelitian}

Metode yang dimanfaatkan pada studi ini merupakan metode eksperimen dengan Rancangan Acak Kelompok (RAK) secara faktorial. Faktor I adalah dosis PGPR(Plant Growth Promoting Rhizobacteria) terdiri dari atas 4 kategori: $\mathrm{KO}(\mathrm{ml}), \mathrm{K} 1(5 \mathrm{ml}), \mathrm{K} 2(10 \mathrm{ml}), \mathrm{K} 3(15 \mathrm{ml})$. Faktor II adalah lama perendaman terdiri atas 4 kategori: P0 (kontrol), P1 (5 menit), P2 (10 menit), P3 (15 menit).

\section{Tahapan Penelitian}

Tahapan penelitian meliputi: persiapan areal penelitian, penyiapan bahan tanam, perendaman, penanaman dan pemeliharaan.

\section{Parameter}

Aspek yang diukur berat kering akar, berat segar akar, berat kering tajing, berat segar tajuk, jumlah daun, panjang sulur, jumlah daun, serta panjang akar.

\section{Analisa Data}

Data diolah menggunakan program SPSS v.25. Data akan diuji menggunakan Data dianalisa dengan memanfaatkan si ik ragam ( Analysis of Variance), dilanjutkan dengan uji DMRT (Duncan's 
Multiple Range Test) dengan signifikan $5 \%$.
Hasil pengamatan panjang sulur Mucuna bracteata dapat ditinjau dari Tabel 1.

\section{HASIL DAN PEMBAHASAN}

\section{Panjang Sulur}

Tabel 1. Rataan berat kering akar, berat segar akar, berat kering tajuk, berat segar tajuk, jumlah daun, panjang sulur, jumlah daun, serta panjang akar pada Umur 8 MST

\begin{tabular}{cccccccc}
\hline Perlakuan & $\begin{array}{c}\text { Panjang } \\
\text { Sulur } \\
\text { (cm) }\end{array}$ & $\begin{array}{c}\text { Jumlah } \\
\text { Daun } \\
\text { (helai) }\end{array}$ & $\begin{array}{c}\text { Berat } \\
\text { Segar } \\
\text { Tajuk } \\
\text { (helai) }\end{array}$ & $\begin{array}{c}\text { Berat } \\
\text { Kering } \\
\text { Tajuk } \\
\text { (gram) }\end{array}$ & $\begin{array}{c}\text { Berat } \\
\text { Segar } \\
\text { Akar } \\
\text { (gram) }\end{array}$ & $\begin{array}{c}\text { Berat } \\
\text { Kering } \\
\text { Akar } \\
\text { (gram) }\end{array}$ & $\begin{array}{c}\text { Panjang } \\
\text { Akar }(\mathbf{c m})\end{array}$ \\
\hline K0P0 & 153.18 & 43.42 & 29.38 & 6.71 & 2.03 & 0.34 & 26.77 \\
K0P1 & 174.93 & 42.92 & 20.48 & 2.93 & 1.08 & 0.19 & 26.77 \\
K0P2 & 165.02 & 44.22 & 23.67 & 5.98 & 1.88 & 0.31 & 23.22 \\
K0P3 & 176.85 & 54.42 & 21.07 & 4.94 & 1.69 & 0.31 & 27.26 \\
K1P0 & 168.44 & 50.25 & 14.87 & 3.5 & 1.48 & 0.28 & 27.65 \\
K1P1 & 148.17 & 47.47 & 23.33 & 6.10 & 1.96 & 0.35 & 25.29 \\
K1P2 & 167.58 & 57.25 & 35.75 & 6.39 & 2.25 & 0.31 & 25.63 \\
K1P3 & 168.18 & 55.00 & 30.28 & 8.01 & 4.24 & 0.52 & 28.99 \\
K2P0 & 155.45 & 46.83 & 26.63 & 4.42 & 1.46 & 0.41 & 26.08 \\
K2P1 & 245.09 & 49.33 & 23.98 & 5.17 & 1.37 & 0.37 & 26.71 \\
K2P2 & 198.19 & 54.00 & 46.33 & 7.12 & 1.18 & 0.37 & 28.41 \\
K2P3 & 172.02 & 49.17 & 51.06 & 4.51 & 1.43 & 0.28 & 27.90 \\
K3P0 & 168.15 & 55.50 & 34.13 & 5.65 & 5.23 & 0.40 & 26.39 \\
K3P1 & 172.68 & 57.17 & 45.73 & 9.09 & 4.41 & 0.41 & 27.73 \\
K3P2 & 160.88 & 48.42 & 18.58 & 4.88 & 1.63 & 0.43 & 29.88 \\
K3P3 & 326.66 & 54.33 & 25.90 & 13.03 & 2.28 & 0.46 & 30.17 \\
\hline
\end{tabular}

Hasil analisa varians menunjukan bahwa panjang sulur Mucuna bracteatatidak berpengaruh terhadap lama perendaman dan perlakuan interaksi serta pemberian dosis PGPR pada pekan ke-2 hingga pekan ke-8. Ada kemungkinan pada saat pemberian dosis PGPR dosisnya terlalu rendah sehingga tidak berpengaru pada panjang sulur Mucuna bracteata. Menurut Iswati, (2012) dosis yang semakin tinggi akan memberi pengaruh yang makin besar terhadap pertubuhan tanaman. Oleh karena itu interaksi serta lama perendaman antara pemberian PGPR dan lama perendaman yang diapikasikan tidak memberikan dampak untuk komposisi media tumbuh Mucuna bracteata sehingga kurang bekerja dalam meningkatan pembelahan sel dan kerja hormon. Dita (2014) menyimpulkan bahwa interaksi antara lama perendaman PGPR dengan dosisr PGR pada tanaman tidak memiliki dampak yang nyata bagi tinggi tumbuhan, jumlah daun, panjang akar, berat akar. selain itu faktor yang mempengaruhi pertumbuhan tanaman disebabkan oleh lingkungan, cuaca dan lainnya, $\mathrm{Hal}$ ini juga didukung berdasarkan penelitian Andrio Sorensen (2015), di musim penghujan dengan curah hujan yang relatif tinggi yang selanjutnya berganti menjadi musim kemarau yang berkepanjangan. Kondisi alam yang ekstrem pada saat penelitian ini bisa mengakibatkan tanaman menjadi tidak menghasilkan bunga maupun biji. Lokasi lahan penelitian juga dapat mengakibatkan plot-plot di lahan studi 
menjadi kering dan terdapat pecahan pada tanah.

adapun pernyataan Gardner et al. (2008) bahwa aspek-aspek yang berpengaruh terhadap perkembangan tanaman di lahan penelitian bisa diklasifikasikan menjadi faktor lingkungan (eksternal) serta faktor genetik (internal). Hal ini dapat mempengaruhi pertumbuhan tanaman tersebut, jika diberi tambahan PGPR membantu menyuburkan sifat fisik dan biologi tanah. Dewi (2008) menambahankan perkembangan tumbuhan tersebut bergantung pada hormon serta dosis larutan yang diaplikasikan karena mungkin saja saat dosis larutan PGPR dinaikan hingga kadar tertentu, namun tidak memberikan pengaruh yang berarti.

\section{Jumlah Daun}

Hasil observasi Jumlah Daun Mucuna bracteata bisa ditinjau melalui Tabel 2 .

Tabel 2. Pengaruh Dosis PGPR Terhadap Jumlah Daun Tanaman Mucuna bracteata pada Umur 2 dan 6 MST.

\begin{tabular}{ccc}
\hline \multirow{2}{*}{ Perlakuan } & \multicolumn{2}{c}{ Jumlah Daun (helai) } \\
\cline { 2 - 3 } & 2 MST & 6 MST \\
\hline K0 & $10,57 \mathrm{ab}$ & $34,97 \mathrm{a}$ \\
K1 & $11,67 \mathrm{~b}$ & $39,67 \mathrm{ab}$ \\
K2 & $10,12 \mathrm{a}$ & $34,89 \mathrm{a}$ \\
K3 & $9,77 \mathrm{a}$ & $41,56 \mathrm{~b}$ \\
\hline
\end{tabular}

Keterangan: Angka yang diikuti notasi yang sama menunjukkan perbedaan yang tidak nyata dengan uji beda rata-rata Duncan pada taraf $5 \%$

Hasil analisa varians menunjukan bahwa jumlah daun tanaman Mucuna Bracteatapemberian PGPR tidak berpengaruh terhadap perlakauan interaksi dan lama perendaman akan tetapi berpengaruh terhadap pemberian dosis biji Mucuna bracteatapada minggu ke-2 dan ke- 6 hal tersebut berhubungan dengan perkembangan vegetatif serta kapabilitas tumbuhan untuk melaksanakan proses maupun metabolit yang lain, terdapat 2 aspek yang berpengaruh terhadap perkembangan tanaman yakni: aspek fenotif serta lingkungan sekitar.

Hakim et al. (1989) menyimpulkan bahwa salah satu bagian yang mempunyai peran utama bagi tumbuhan ialah daun. Jumlah daun sangat mempengaruhi hasil fotosintesis, yang nantinya akan memberikan pengaruh bagi pertumbuhan serta perkembangan tumbuhan. Namun berdasarkan uji statistik aplikasi PGPR terhadap pertumbuhan jumlah daun bibit Mucuna bractetatidak berpengaruh pada saat perendaman dan 2 faktor interaksi lama perendaman dan dosis, Hal ini dikarenakan terjadi antara faktor tersebut masih dalam kurang berpotensi dalam merangsang kerja hormon sehingga secara signifikan belum dapat meningkatkan pertumbuhan daun. berdasarkan data Tabel 2 perlakuan $\mathrm{K}$ pada minggu ke-2 dan ke-6 dapat meningkatkan pertumbuhan daun dengan uji SPSS. hal ini disebabkan karena pada saat pemberian PGPR tepat dengan dosisnya. Trenkel et al. (2010).

menyatakan bahwa proses pembentukan daun mendapatkan pengaruh besar dari unsur fosfor serta nitrogen yang berada pada medium tumbuh tersebut. Unsur tersebut memiliki peran dalam pembentukan sel-sel baru serta berfungsi sebagai salah satu unsur yang menyusun senyawa organik pada tumbuhan contohnya ATP, ADP, klorofil, asam nukleat, maupun asam amino dan metabolisme yang dapat terhambat jika tanaman tidak mendapat nitrogen yang cukup. Namun bahwa unsur hara diberikan terlalu banyak dapat mengakibatkan keracunan bagi tumbuhan yang akan memperlambat pertumbuhan serta perkembangannya, bahkan pada kondisi yang berkelanjutan mampu mengakibatkan kematian pada tumbuhan (Gusniwati et al. 2012). 


\section{Berat Segar Tajuk (g)}

Informasi rataan pengamatan terhadap pertumbuhan berat basah tajuk setelah pemberian PGPR dan lama perendaman pada pekan ke-8 bisa ditinjau melalui lampiran 17. Menurut hasil analisis of varians (ANOVA) terdapat pada lampiran 18. Bahwa pemberian dosis PGPR dan lama perendaman, serta interaksinya dengan durasi perendaman memiliki dampak yang tidak nyata atas berat segar tajuk bibit Mucuna bracteatapada minggu ke-8. Hal ini dikarenakan tanah yang kurang menggembur sehingga penyerapan unsur hara tidak optimal. Sesuai dengan pernyataan yang Nelson (2004), bahwa bakteri PGPR mampu menghasilkan keuntungan dalam proses pertumbuhan serta fisiologi tanaman, contohnya dengan menghasilkan serta memodifikasi kadar fitohormon yang memicu pertumbuhan tanaman, memperbanyak ketersediaan nutrisi untuk tanaman dengan memfasilitasi serta mendistribusi penyerapan untuk beraneka ragam zat hara dalam tanah guna meminimalisir pertumbuhan penyakit atau hama.

Perkembangan tumbuhan dapat terhambat apabila tidak terdapat unsur hara tambahan yang bersumber dari pupuk yang mampu menurunkan kadar biomassa. Adanya penurunan pertumbuhan paramater tersebut diakibatkan oleh pemberian dosis pupuk yang tinggi sehingga memperlambat penyerapan air serta hara yang berhubungan dengan proses fotosintesis. Proses fotosintesis selain mendapatkan klorofil, air, dan cahaya juga memerlukan energi, pasokan hara $\mathrm{P}$ serta enzim (Richardson et al., 2009; Bar Tal, 2011).

\section{Berat Kering Tajuk (g)}

Berdasarkan hasil observasi menunjukan dari data berat kering tajuk (g) biji Mucuna bracteata pemberian dosis PGPR pada 12 Minggu Setelah Tanam (MST) kombinasi perlakuan dosis dan durasi perendaman tidak berdampak atas berat kering tajuk biji Mucuna bracteata, terdapat pada lampiran 19 dan selanjutnya hasil analisa sidik ragam terdapat pada lampiran 20. berat kering tajuk tanaman adalah hasil dari biomassa dari batang sampai dengan daun yang muncul dari fotosintesis. Sel-sel yang memiliki berat basah yang tinggi memiliki banyak air, sehingga berat kering yang dimiliki lebih kecil, akibatnya saat pengeringan, air yang terdapat pada sel akan berevaporasi sampai habis dan menurunkan berat kering (Wardani 2004), Pengukuran berat kering merupakan indikator hasil fotosintesis suatutanaman. Lakitan (2006), menyimpulkan bahwa berat kering tumbuhan menggambarkan gabungan dari unsur organik yang dapat disentisis, khususnya karbondioksia serta air dari zat hara yang diserap serta hasil fotosintesis tanaman.

\section{Berat Segar Akar (g)}

Hasil pengamatan Berat Segar AkarMucuna bracteata bisa ditinjau melalui Tabel 3.

Tabel 3. Pengaruh Dosis PGPR Terhadap Berat Segar Akar Tanaman Mucuna bracteata pada

Umur 8 MST.

\begin{tabular}{|c|c|}
\hline \multirow{2}{*}{ Perlakuan } & Berat Segar Akar \\
\hline & 8 MST \\
\hline K0 & $1,67 \mathrm{a}$ \\
\hline K1 & $2,48 \mathrm{ab}$ \\
\hline K2 & $1,36 \mathrm{a}$ \\
\hline K3 & $3,39 \mathrm{~b}$ \\
\hline
\end{tabular}

Keterangan: Angkayang diikuti notasi yang sama menunjukkan tidak berbeda nyata dengan uji beda rata-rata Duncan pada taraf $5 \%$ 
Data rataan hasil pengamatan terhadapberat segar akar tanaman Mucuna bracteta setelah pemberian PGPR pada minggu ke 8 dapat dilihat dari pada Tabel1. Berdasarkan hasil (ANOVA) terdapat pada Tabel 3. bahwa durasi perendaman dan interaksinya kombinasi antara pemberian dosis dan durasi perendaman memiliki dampak yang tidak nyata terhadap berat segar akar tanaman Mucuna bracteata pada 8 MST.

Akan tetapi pengaplikasian dosis PGPR berpengaruh terhadap kenaikan berat segar tanaman Mucuna bracteata. Hal ini dikarenakan pada saat pemberiandosis PGPR dosis tersebut bereaksi didalam tanah yang lembabsehingga jumlah terbaik di peroleh pada perlakuan K3P0 dengan hasil 5.23 g. Namun tidak berpengaruh sama sekali dengan perendaman, disebabkan semakin lama perendaman biji Mucuna bracteta dilakukan, maka biji akan menggelembung besar dan kulitnya akan terlepas dapat mengakibatkan munculnya jamur dan tanaman mengalami kematian, Bakteri pada tanah menghasilkan manfaat bagi tumbuhan, namun bakteri dipengaruhi oleh kelembaban tanah, temperature, $\mathrm{pH}$, maupun unsur organik tanah dan mikroorganisme tanah lainnya (Kizilka ya,2009).

Namun dalam hal ini mikroorganisme tidak dapat bekerja dalam menginfeksi akar seolah tidak mempengaruhi biomassa berat segar, Infeksi mikoorganisme terletak pada akar tanaman mampu mengakibatkan perubahan morfologi pada tanaman, yakni mikoorganisme akan menyerap unsur hara serta air dari dalam tanah, menggantikan fungsi akar serta hifa eksternalnya (Prasasti et al., 2013).

\section{Berat Kering Akar (g)}

Hasil observasi Berat Kering Akar Mucuna bracteata bisa ditinjau melalui Tabel 4

Tabel 4. Pengaruh Dosis PGPR Terhadap Berat Kering Akar Tanaman Mucuna bracteata pada Umur 8 MST.

\begin{tabular}{cc}
\hline \multirow{2}{*}{ Perlakuan } & Berat Segar Akar \\
\cline { 2 - 2 } & 8 MST \\
\hline K0 & $28,75 \mathrm{a}$ \\
K2 & $35,75 \mathrm{ab}$ \\
K3 & $36,37 \mathrm{ab}$ \\
\end{tabular}

Keterangan: Angka yang diikuti notasi yang sama menunjukkan tidak berbeda nyata dengan uji beda rata-rata Duncan pada taraf $5 \%$ 
Menurut uji lanjut DMRT dengan kadar $5 \%$ perlakuan pengaplikasian dosis PGPR dapat mempercepat pertumbuhan berat kering akar tanaman Mucana bracteta pada minggu ke-8 setelah tanam pada perlakuan $\mathrm{K} 3$ dengan dosis $15 \mathrm{ml}$ mencapai hasil sebesar 42,67 $\mathrm{g}$ dan terendah perlakuan $\mathrm{KO}$ dengan dosis $0 \mathrm{ml}$ mencapai hasil $28,75 \mathrm{~g}$. Hal ini menunjukan kenaikan berat kering akar tanaman Mucuna bracteta yang semakin tinggi dipengaruhi oleh tingginya kadar dosis PGPR yang diberikan

\section{Panjang Akar (cm)}

Berdasarkan hasil analsis of

varians (ANOVA) bahwa pemberian dosis PGPR dan lama perendaman, serta interaksinya dengan durasi perendaman tidak memiliki dampak nyata akan panjang akar tanaman Mucuna bracteatapada minggu ke-8. Hal ini kemungkinan kurang tinggi dosis PGPR yang diaplikasikan sehingga mikroorganisme media tanam kurang berpotensi untuk merangsang pertumbuhan akar.

Menurut Anita et al.,(2015),Menjelaskan bahwa faktor dari genetik, morfologi akar juga dipengaruhi oleh ketersediaan hara. jika zat hara yang ada dapat mencukupi nutrisi tumbuhan maka tumbuhan akan menyusun sistem akar yang dangkal, oleh karena itu dalam penelitian ini pada aplikasi pemberian dosis PGPR dan lama perendaman serta kombinasi dosis dan lama perendaman PGPR akar pada tanaman tidak panjang karena unsur hara didalam tanah sudah memenuhi kebutuhan pada tanama n Mucuna bractetata.

\section{KESIMPULAN}

1. Pemberian larutan PGPR berpengaruh atas berat kering akar, berat segar akar, serta jumlah daun tanaman Mucuna bracteata.

2. Pemberian larutan PGPR dengan durasi perendaman tidak berdampak bagi berat kering akar, berat segar akar, berat kering tajing, berat segar tajuk, jumlah daun, panjang sulur, jumlah daun, serta panjang akar tumbuhan Mucuna bracteata.

3. Interaksi antara pemberian larutan PGPR dengan waktu perendaman tidak berpengaruh seluruh parameter pertumbuhan tanaman Mucuna bracteata.

\section{DAFTAR PUSTAKA}

Afrianti, S., Pratomo, B., \& Daulay, D. M. (2019) Aplikasi cangkang telur ayam boiler dan pupuk mikoriza terhadap pertumbuhan bibit kelapa sawit (elaeis guineensis jacq) pada tanah sulfat masam di pre nursery. [Skripsi]. Fakultas Agroteknologi: Universitas Prima Indonesia. Medan

Nugroho, T. C., Oksana, O., \& Aryanti, E. (2013). Analisis Sifat Kimia Tanah Gambut yang Dikonversi Menjadi Perkebunan Kelapa Sawit di Kabupaten Kampar. Jurnal Agroteknologi, 4(1), 26-30. https://doi.org/10.24014/ja.v4i1.60

RR Darlita, R. D., Joy, B., \& Sudirja, R. (2017). Analisis Beberapa Sifat Kimia Tanah Terhadap Peningkatan Produksi Kelapa Sawit pada Tanah Pasir di Perkebunan Kelapa Sawit Selangkun. Agrikultura, 28(1), 15-20. https://doi.org/10.24198/agrikultura.v2 8i1.12294

Rukmi, Bratawinata, A. A., Pitopang, R., \& Matius, P. (2017). Sifat Fisik Dan Kimia Tanah Pada Berbagai Ketinggian Tempat Di Habitat Eboni (Diospyros celebica Bakh.) DAS Sausu Sulawesi Tengah. Warta Rimba, 5(1), 28-36.

Soil, C. L. (2011). Pengaruh Pemberian Bahan Organik Pada Tanah Liat Dan Lempung Berliat Terhadap Kemampuan Mengikat Air. Jurnal IImu Pertanian Indonesia, 16(2), 130135.

Suryani, I. (2014). Tanah Pada Areal 
Konversi Lahan Hutan. 10(2), 99106.

Utami, S. N. H., \& Handayani, S. (2003). Sifat Kimia Entisol Pada Sistem Pertanian Organik. IImu Pertanian, 10(2), 63-69.

Vasu, D., Srivastava, R., Patil, N. G., Tiwary, P., Chandran, P., \& Kumar Singh, S. (2018). A comparative assessment of land suitability evaluation methods for agricultural land use planning at village level. Land Use Policy, 79(August), 146163.

https://doi.org/10.1016/j.landusepol.2 018.08.007

Wirdhana Ahmad, S. (2014). Peranan Legume Cover Crops ( LCC ) Colopogonium mucunoides DESV . Pada Teknik Konservasi Tanah Dan Air Di Perkebunan Kelapa Sawit. Prosiding Seminar Nasional Biologi Dan Pembelajarannya, (Lcc), 341346. 